\title{
ISLAMIC BEHAVIOR HABITS AS A CULTURAL SCHOOL (CASE STUDY IN SMAN 3 BOJONEGORO)
}

\author{
Muh. Muhtarom \\ SMA Negeri 3 Bojonegoro \\ muhammadmuhtarom88@gmail.com
}

\begin{abstract}
This Reseach aimed to explore how Islamic behavior habits strategy in SMAN 3 Bojonegoro, how Implementation of Islamic behavior habits in SMAN 3 Bojonegoro, and how the implications of Islamic behavior in SMAN 3 Bojonegoro. The method of this research was qualitative approach with case study design, its location is in State Senior High School 3 Bojonegoro, source of informant, event, location and document, primary and secondary data, data collecting technique with participant observation, interview and documentation. Data analysis with single case analysis, while checking its data validity by using peer discussion, triangulation method, triangulation of data source, time triangulation. The results of this study showed that: 1) Planning habituation of Islamic behavior starting from the formulation of vision and mission of Islami, until the preparation of standard ubudiyah. To familiarize Islamic behavior, Islamic religious education teachers familiarize religious behavior and plan religious activities in educational institutions. Planning of such religious activities as one of the means to create a religious atmosphere as the development of Islamic education learning in the school, 2) Habituation of Islamic behavior starting from daily activities, weekly, monthly to annual, and 3) Islamic behavior habits can form the Muslim personality on students in educational institutions. The Muslim person with the qur'ani character could be formed through the habituation of religious activities in the institution.
\end{abstract}

Keywords: Habituation, Islamic Behavior. 


\section{A. Introduction}

Education plays a very important role in the process of improving the quality of Human Resources (HR). In the world of education, the school is one of the places where the process of Transfer of knowledge takes place. The process of teaching and learning in schools is expected to fight for and realize the quality of education in Indonesia.

The role of education in developing the potential of human believers in accordance with UU SISDIKNAS No. 20 Year 2003 which states that "National Education function to develop ability and form the character and civilization of dignified nation in order to educate the life of the nation, aims to the development of the potential of learners to become human beings who believe and piety to God Almighty, noble, healthy, knowledgeable, capable, creative, independent, and become a democratic and responsible citizen ". ${ }^{1}$

Worship in Islam has a broad concept, both in terms of content, time and place. In terms of content, the government that upholds justice among human beings, for example, is in the category of worship to Allah SWT. Likewise, the believer is intended to achieve the pleasure of Allah SWT included in the sense of worship. On the basis of these principles, the educational process is also a worship to Allah SWT. Teachers who teach kindness to others are people who worship Allah SWT, as well as students who are searching for the truth. ${ }^{2}$ While religious education is an attempt to strengthen the faith and devotion to God Almighty according to the religion adopted by learners. While the Islamic Religious Education in schools is expected to form a social piety, so that with religious education is expected to create ukhuwah islamiyah in the broad sense ukhuwah fi al-'ubudiyah, ukhuwah fi al-insaniyah, ukhuwah fi al wathoniyah wa al nasab, and ukhuwah fi din al Islam. ${ }^{3}$

Islamic Religious Education is one of the important and indispensable things in the development of science in facing the challenges of an increasingly advanced era. However, on the other hand, religious education is regarded as a lesson that in the second for students.

\footnotetext{
${ }^{1}$ Tim Redaksi Sinar Grafika, Undang-Undang Sistem Pendidikan Nasional (Nomor 20 Tahun 2003), (Jakarta: Sinar Grafika, 2007), 39.

${ }^{2}$ Heri Nur Munzier S, Watak Pendidikan Islam, (Jakarta: Friska Agung Insani, 2008), 56.

${ }^{3}$ Muhaimin, Paradigma Pendidikan Islam (Bandung: PT Remaja Rosada Karya, 2004), 76.
} 
Then in other respects, in this era of globalization many challenges for students who can threaten their physical health and soul. Not a few children who show unhealthy behavior, such as prefer to consume unhealthy foods high in fat, sugar, salt, low fiber, increase the risk of hypertension, diabetes, obesity, and so on. Especially before eating do not wash hands first, to enable the seeds of disease into the body.

The students also tend to prefer and watch a lot of television, playing video games, and play station, resulting in physical discomfort. As a result, they are susceptible to experiencing pain and are at risk for various degenerative diseases at an early age. Therefore, Islamic behavior in schools and surrounding communities is required. It is very supportive and allows learners to learn, create freely, fun and beneficial for the future.

Given the importance of the role of Islamic Religious Education, both in the formal sense, namely the reasoning and the formation of the personal nature of the students, as well as in the material sense, namely the mastery, application, and skills of Islamic Religious Education, it should be that the learning process of Islamic Religious Education needs serious attention, among them through the habituation of Islamic behavior. Islamic education should be able to equip learners with life skills that match the needs of the environment and the needs of learners.

In the habituation of Islamic behavior as a school culture it is necessary to have courage to express an opinion, it is necessary to implement Islamic Religious Education in public school community, so that the learning of Islamic Religious Education is more meaningful and useful. In this case the teacher of Islamic Education must be creative in building effective strategy in Habituation of Islamic Behavior as School Culture. So, the teacher of Islamic Religious Education does not stand alone in this habituation, but also able to move the teacher of other study field to synergize and equally pro active in sponsoring the realization of Behavior of Islamic Behavior as School Culture.

Awareness of the importance of Islamic Religious Education in the life of the younger generation in schools can be realized in the habituation of Islamic behavior. This is done because the awareness of building the nation will reap success if the perpetrators have quality resources and have a good awareness of Islam and awareness of the environment. Therefore, students must understand and master the 
values of Islam as the basis of life.

In Law no. 20 of 2003 on the National Education System has occurred a reform of thought about education in the form of assertion that education emphasizes to realize the learning atmosphere and the learning process, and the involvement of learners actively develop the potential of learners, the recognition of the diversity of learners and therefore educators must interact with diversity of learners.

Regarding the educational paradigm contained in article 1, paragraph 1 as mentioned above, in article 1, paragraph 2 of Law no. 20 of 2003 affirmed that: "National Education is education based on Pancasila and the 1945 Constitution of the Republic of Indonesia which is rooted in the values of religion, national culture of Indonesia and the responses of the changing demands of the times". ${ }^{4}$

To realize the values of religion in school it is necessary to provide spiritual enlightenment to build noble character or character through habituation activities, such as: habituation to say hara, congregation prayers dhuhur congregation, dhuha prayer habitation, alms donation, reading al-quran habituation, and habituation commemorating the Islamic Day.

Based on the above description, the researchers tried to examine the Habituation of Islamic Behavior in SMAN 3 Bojonegoro. The reason the researchers took the location in this place was in the background by some considerations on the basis of uniqueness and attractiveness, ie the institution is an educational institution within the Ministry of Education and Culture, which in the habituation of Islamic behavior is so highly regarded. SMA Negeri 3 Bojonegoro. This high school became the favored public high school people of Bojonegoro. Moral coaching at this institution seems good and interesting to be in carefully.

\section{B. Research Methods}

The focus of this research is on Habituation of Islamic Behavior in SMA 3 Bojonegoro, using a qualitative approach. The qualitative approach the researcher uses because the object under study takes place in a reasonable setting and aims to know, understand, and live more thoroughly and in more depth about how the Habituation of Islamic Behavior in SMAN 3 Bojonegoro.

\footnotetext{
${ }^{4}$ Undang-Undang Pemerintah ... 75.
} 
Ahmad Tanzeh quoted from Margono suggests that qualitative research is a research that basically uses deductive and inductive approach means that the approach departs from a theoretical framework, the ideas of experts, as well as the understanding of researchers based on experience, then developed into problems and solutions proposed to obtain justification in the form support of empirical data in the field. ${ }^{5}$ Furthermore, the type of research used in this research is field research by using multi case design study, that is trying to describe a certain background, object or event in detail and depth. ${ }^{6}$ The main characteristic of multi case studies is when the researcher examines two or more subjects, backgrounds or data storage.

As a multi case study study, the steps to be taken in this research are as follows: 1) perform data collection in the first case, that is Habituation of Islamic Behavior which research will be done until the data saturation level 2) the second case, namely the School Culture in SMAN 3 Bojonegoro where the research would be done up to the data saturation level as well.

1. Instrument Research (Researcher Presence)

The presence of researchers in the field in qualitative research is a liability that must be done, because researcher is key's instrument. ${ }^{7}$ In this study, researcher come directly to the research location of the educational institution. $\mathrm{T}$ he researchers will come to the site to conduct research in the field. The researcher sees and follow the activities directly with fixed based on certain principles or codes of ethics that must be obeyed by researchers. For that, the presence of researchers is necessary to obtain comprehensive and intact data.

2. Data Source

The data source is from which data is obtained. ${ }^{8}$ The main source of data in qualitative research is the data source of words, actions and the rest are additional data such as from dukumen and so on. Words obtained from interviewees can be recorded through written notes or through video recordings, tapes, photographs or films. ${ }^{9}$

\footnotetext{
${ }^{5}$ Ahmad Tanzeh, Pengantar Metode Penelitian, (Yogyakarta: Teras, 2009), 66

${ }^{6}$ Yatim Riyanto, Metodologi Penelitian, (Surabaya: SIC, 2004), 24

${ }^{7}$ Sugiyono, Metode Penelitian Pendidikan: Pendekatan Kuantitatif, Kualitatif, Dan R\&D, (Bandung: Alfabeta, 2008), 310

${ }^{8}$ Suharsimi Arikunto, Prosedur Penelitian Suatu Pendekatan Praktis (Edisi Revisi VI), (Jakarta: PT.Reineka Cipta, 2006), 129

${ }^{9}$ Moleong, Metodologi Penelitian Kualitatif, (Bandung: Remaja Rosdakarya, 2005), 112.
} 
This is the full explanation:

a. Resource (Informant)

In determining the informant, the researcher uses purposive sampling, internal, and time sampling. Based on purposive technique, the researcher specifies key informants: principal, vice principal, and head of administration. This purposive technique is used to select and select informants who really master the information and problems in depth. From this informant was then developed to other informants with snowball sampling technique with the aim to obtain the accuracy of the data obtained. In addition, with this technique will get data that is continuous, accurate, complete, and profound.

Sampling taking with internal sampling is the researcher trying to focus the idea of what is being studied, with whom will the interview, when to do the observation and what documents are needed. This is done by conducting interviews, observations and documentation studies across data sources. While the sampling technique with time sampling that researchers take data by visiting the location or informants based on the time and condition of the place, because the situation around affect the data collected. In this case the importance of researchers can consider the time and place to meet with informants.

b. Event

Events are used to find out how the learning process or program is being used as a follow up of the strategic planning undertaken. Researchers present and directly see what programs are running in the school location of the study.

c. Document

Documents are written materials or objects related to research focus. Documents in this research are field notes, recordings, pictures, or objects related to all matters relating to the Habituation of Islamic Behavior as a School Culture.

\section{Data Collection Techniques}

In a study there are various data collection techniques tailored to the nature of the research used. Techniques used by researchers in this study are: 
a. In-depth interview (indepth interview)

In qualitative research, the interview method used is the in-depth interview method (indepth interview) that is the conversation conducted to obtain opinions, perceptions, feelings, knowledge, and the sensory experience of the informant about the problems studied. ${ }^{10}$ Interview method is used by researchers to interview principals, teachers, and also students at SMAN 3 Bojonegoro to get accurate information to complete the data. The interview steps in this study were conducted in order of: 1) determining who the interview informant was, 2) preparing the materials for the interview, 3 ) initiating and opening the interview, 4) conducting the interview, 5) confirming the interview result, 6) writing the interview result, 7 ) identifies follow-up interview results.

Applicatively, in this in-depth interview after interview with the first informant is considered enough, then the researcher asks to show the next informant who is considered to have the required information and do enough interviews. And so on until in accordance with the objectives contained in the focus of research.

b. Participant Observation

Obsevation of participants is interpreted as a systematic observation and recording of the symptoms that appear in the object of research. ${ }^{11}$ In the observation of this participant observation, the researcher was present in the research location and tried to notice and record every phenomenon that arises in SMAN 3 Bojonegoro in relation to the phenomenon studied is about Habituation of Islamic Behavior.

In this study, researchers conducted the first stage of participant observation, which started from the descriptive observation widely by describing in general the situation of both institutions. The next stage is done with focused observation to see things related to the research focus. The last stage is to conduct a selective observation by looking for differences among the things studied based on the research focus.

\footnotetext{
${ }^{10}$ Ahmad Tanzeh, Pengantar Metode Penelitian, (Yogyakarta:Teras, 2009), 183

${ }^{11}$ Sugiyono,Metode....308
} 


\section{c. Documentation}

Documentation method is to find data about things or variables in the form of notes, transcripts, books, newspapers, inscriptions, minutes of meetings, agenda, and so forth. ${ }^{12}$ In this research, documentation method is used to find data about the Habituation of Islamic Behavior in SMAN 3 Bojonegoro. Documentation is used to overcome the previous data obtained from indepth interview and field observation. Documents here may include photos, agency documents, interview transcripts.

While the instrument in this study, in accordance with the nature of qualitative research, the main instrument is the researchers themselves assisted by tools: cameras, tape recorders and other tools that support the achievement of the desired data

4. Data Analysis

Data analysis is a process of finding and organizing systematically transcripts interviews, field notes, and other materials that have been collected by researchers. Analytical work is done by reviewing data, organizing, dividing into manageable units, synthesizing, finding patterns, finding what is meaningful, and what will be studied and reported systematically. ${ }^{13}$

Analysis of individual case data in this study was conducted on each object namely: SMAN 3 Bojonegoro. In analyzing the researchers to interpret the data in the form of words, so that the meaning obtained. Miles and Huberman as quoted by Sugiyono, argued that the activity in qualitative data analysis done interactively and lasted continuously until complete, so the data is saturated. ${ }^{14}$ Descriptive qualitative research uses data analysis, while the steps are:

a. Data reduction

Reducing data means summarizing, selecting the key points, focusing on the essentials, looking for themes and patterns, and removing unnecessary ones. ${ }^{15}$ In the data reduction phase, researchers use taxonomic analysis techniques. This technique is done by collecting data in the field continuously

\footnotetext{
${ }^{12}$ Suharsimi, Prosedur....,231

${ }^{13}$ Ibid...168

${ }^{14}$ Sugiyono, Metode.....337

15 Ibid....338
} 
through the observation of participants, in-depth interviews, and documentation, so that the data collected into many. After the overall data collected, then by the researchers the data is described in more detail and depth. ${ }^{16}$

b. Data Presentation

After the data on Habituation of Islamic Behavior in both institutions is reduced, then the next step is data presentation. Presentation of data can be a brief description, charts, relationships between categories, flowcharts, and the like. While the data are often used in qualitative research is with text that is narrative ${ }^{17}$ By presenting the data on how to Habituate Islamic Behavior in the two institutions, it will make it easier to understand what is happening, plan the next work based on what has been understood.

c. Withdrawal Conclusion

The conclusion in the expected qualitative study is a new finding that has not previously existed. The findings can be a description or description of an object that was previously still gray, so that after the examination becomes clear. These three stages take place simultaneously. The analysis of this data is illustrated as follows:

5. Checking the Invalidity of Findings

To ensure the trust and validity of data obtained through research, it is necessary to test the validity of data and data feasibility, namely by: ${ }^{18}$

a. Discussion

By way of exposing the interim results obtained in the form of analytic discussions with colleagues who have skills related to style and about improving the quality of education. From the information that has been excavated, it is hoped that there could be a different opinion meeting, which will further strengthen the research result. In this peer review the researcher did this with some people who were involved and assisted in the research process, such as teachers, staff at SMAN 3 Bojonegoro who then together discuss the data obtained by researchers during the field.

\footnotetext{
${ }^{16} \mathrm{Ibid}, \ldots . .365$

${ }^{17}$ Ibid, ...141

${ }^{18}$ Lexy J. Moleong, Metode Penelitian Kualitatif, Bandung: Remaja Rosdakarya, 2000, 154
} 
b. Triangulation

Triangulation is essentially a multimetode approach by researcher when collects and analyzes data. The basic idea is that the observed phenomenon can be well understood to obtain high-level truths when approached from different points of view. Taking pictures of a single phenomenon from different angles will allow for a reliable level of truth. Therefore, triangulation is an attempt to check the correctness of data or information obtained by researchers from different angles by reducing as much bias as possible when gathering and analyzing data.

As known in qualitative research the researcher itself is the main instrument. Therefore, the quality of qualitative research is highly dependent on the quality of self-researcher, including his experience in conducting research is something that is very valuable. The more a person experiences in doing research, the more sensitive the symptoms or phenomena being studied. However, as a human being, a researcher is difficult to avoid bias or subjectivity. Therefore, the researcher's task reduces as much as possible the biases that occur to obtain the complete truth.

In this research, the researcher uses triangulation method technique, source triangulation and time triangulation are: ${ }^{19}$

1) Triangulation method

Done by comparing information or data in different ways. As known, in qualitative research the researcher uses interview, observation, and survey methods. To obtain the truth of reliable information and a complete picture of certain information, researchers can use free interview methods and structured interviews. Or, the researcher uses interviews and observations to check the truth. In addition, researchers can also use different informants to check the truth of the information. Through various perspectives or views expected to obtain results that are close to the truth. Therefore, triangulation of this stage is done if the data or information obtained from the subject or informant is doubtful. Thus, if the data is clear, for example in the form of text or script / transcript of film, novel

\footnotetext{
${ }^{19} \mathrm{http} / / /$ mudjiarahardjo.com diunduh tanggal 5 maret 2015
} 
and the like, triangulation is not necessary. Nevertheless, triangulation of other aspects remains to be done.

2) Triangulation of data sources

That is exploring the truth of certain information through various methods and sources of data acquisition. For example, other than through interviews and observations, researchers can use participant observation, written documents, archives, historical documents, official records, personal notes or writings and pictures or photographs. Of course, each way it will produce different evidence or data, which will then provide different insights about the phenomenon being studied. Those views will give birth to the breadth of knowledge to obtain reliable truth.

In its application, triangulation of resources conducted by researchers by checking the data that has been obtained through several sources in SMAN 3 Bojonegoro, such as Principals, Teachers, Teachers, and Students. Data from these three sources are then described, categorized, between the same view, the different, and the specific. The data has been analyzed by the researcher to generate a conclusion, then request agreement (member check) from four sources of data. While in triagulation method, researchers do it by checking the data to the same source but by using different techniques. For example, data obtained by interview method to the Principal, then checked with observation method and documentation. If the three methods produce different data, the researcher then conducts further discussions to the relevant data source to ascertain which data are considered correct or may be true because the point of view is different.

3) Triangulation of Time

The time also often affects the credibility of the data. Data collected by interview technique in the morning when the resource is fresh, not many problems, will provide more valid data so credible. ${ }^{20}$

For that to test the credibility of data can be done by checking with interviews, observations or other techniques in different times and

\footnotetext{
${ }^{20}$ Sugiono, Memahami Penelitian Kualitatif, (Bandung: Alfabeta, 2014), 127.
} 
situations. If the test results produce different data then, done repeatedly so until found the data certainty.

\section{Results and Discussion}

1. Strategy of Habituating Islamic Behavior

According to the analysis chosen by the researcher is descriptive qualitative data analysis technique or the exposure of data analysis result obtained from the observation, interview, field note, and other materials that have been collected by researcher to be reported. Researchers process data collected through interviews, observations, field notes, and documents. Then the data is analyzed in such a way that it becomes the exposure of data that is easily understood and then processed with a qualitative approach.

Data obtained and presented by the researchers will be analyzed with reference to the focus of the problem that has been set. Below is the result of analysis that has been done by the researcher, that is:

a. To obtain data on Islamic behavior habits contained in SMAN 3 Bojonegoro, researchers used interview and observation methods. Based on research findings that have been disclosed above about the habituation of Islamic behavior in SMAN 3 Bojonegoro. Where originally habituation begins with the policy taken by MKKS in Bojonegoro. So, the teacher made a change paradigm thinking citizens of SMAN 3 Bojonegoro, that is by the effort of habituating Islamic behavior in the school environment, which refers to the vision of SMAN 3 Bojonegoro.

b. To familiarize Islamic behavior in every educational institution that is by formulating and preparing school vision and mission, planning the program when the beginning of the lesson year, compilation of strategic plan (renstra) and involving all stakeholders in planning activity of habituation of Islami behavior.

c. In an effort to habituate Islamic behavior in SMAN 3 Bojonegoro takes a long time considering the input of students at SMAN 3 Bojonegoro is diverse, some are from junior high school and some are from MTs, thus requiring gradual coaching, familiarizing, giving examples and limited to implementation of 
Islamic religious education because SMAN 3 Bojonegoro is a public school.

d. Regarding the condition of learners in religious matters there are differences each year, principals explain the students who register there are from junior high school and some of the MTs, they have a good knowledge of religion and there are still little know about religion. Although some learners already have the motivation to realize the habituation of Islamic behavior.

2. Implementation in Accustoming to Islamic Behavior

a. Apply Habituation

Imam Al Ghazali in his book Ikhya 'Ulumuddin states that morality is a picture of behavior in the soul from which the deeds are born easily without the need for thought and consideration. ${ }^{21}$ There are some habits applied by the principal to familiarize Islamic behavior, among them: doing congregational prayer, reading al qur'an, praying before the lesson, courtesy, keeping clean, being honest, greeting and shaking with the teacher.

To change it often requires serious therapy and self-control. For parents and teachers, habituation should be accompanied by an effort to raise awareness or an ongoing understanding of the intentions of accustomed behavior. Because, habituation is used not to force learners to do something optimistic like a robot, but that he can do all the good with ease without feeling hard or heavy heart.

b. To apply some intensive and consistent religious activities, whether conducted daily, weekly or monthly and some are carried out incidentally.

Religious education is a joint duty and responsibility of not only religious teachers but also the duties and responsibilities of teachers of other fields or schools. Religious education is not only limited to aspects of knowledge, but also includes the formation of attitudes, behavior and religious experience. For that the formation of attitudes, behaviors, and religious experience was not only done by religious teachers but should be supported by guruguru other fields of study.

Religious activities carried out by the headmaster in the habit of Islamic behavior, namely: reading asmaul husna, jum'at charity, read write al qur'an,

\footnotetext{
${ }^{21}$ Muhammad Alim, Pendidikan, 151.
} 
istighasah, anniversary of Islam, Ramadan, collection and distribution of zakat fitrah, halal bihalal, prayer 'eid adha and slaughter of qurban animals.

c. Giving exemplary

According to the interpretation, a strategy that educational practitioners can do to shape religious culture in schools is through example or example.22 In the Qur'an there are many verses that indicate the importance of the use of exemplary in education, among others seen in the verses that propound the exemplary individuals as in the Messenger of Allah. Among them in the letter al ahzab verse 21 :

"The Messenger of Allah is a good example for you who is in expectation (grace) of Allah and (the coming) of the Day of Resurrection, and he calls Allah a lot" (Surah Al Ahzab: 21). ${ }^{23}$

In addition to more verbal morale support, the principal also provides support to the school community with concrete actions in the form of participation in carrying out activities undertaken at the school.

3. Implications of Habituating Islamic Behavior

Islamic behavior can form the Muslim personality in the students. The Muslim person can be formed through the religious activities that exist in the secondary education institutions. It is very appropriate that religious activity is something that must be created in educational institutions, because it is one of the efforts to transform the value or conduct value education. Besides religious activities are one of the vehicles to transfer the value to the learners. Without religious activity, educators can find it difficult to transfer value to students and transfer the value is not enough just to rely on learning in the classroom. Because learning in the average class only deepens the cognitive aspect only.

\section{Conclusions}

1. Strategy of Habituating Islamic Behavior

\footnotetext{
${ }^{22}$ Ahmad Tafsir, Metodologi Pengajaran Agama Islam, (Bandung: PT. Remaja Rosdakarya, 2004), 112.

${ }^{23}$ Departemen Agama, Al Qur'an dan Terjemahannya, 670.
} 
Strategy to familiarize Islamic behavior begins vision and mission formulation that is formulation of vision and mission of education institution, compilation of program and religious activity and preparation of Ubudiyah and Akhlakul karimah (SKUA) Standards of Skills which involves all stakeholders in planning up to implementation strategy of Islamic behavior habituation activity.

In addition, to familiarize Islamic behavior, Islamic religious education teachers familiarize religious behavior and plan religious activities in educational institutions. Planning of religious activities is one of the means in order to create a religious atmosphere as the development of Islamic education learning in the school.

The planning of Islamic behavior habituation starts from the formulation of the objectives to be achieved then the determination of the field / function / unit as the parts that would carry out the activities to achieve the goals and set the required timeframe, set the strategy to achieve the goal, set the tools used for the efficiency of achieving the goals, formulate the evaluation plan, determine the amount and source of necessary funds and the making of religious programs, the preparation of the standard of ubudiyah skills and akhlakul karimah.

2. Implementation Habituation of Islamic Behavior

Habituation of Islamic behavior starts from the program determined at the beginning of the year, then implemented starting from daily activities, weekly, monthly, to annual. After the students are accustomed to carrying out all school activities, the expectation is that children can apply Islamic behavior wherever they are. They still apply the habits of greetings, smiles, greetings, dressing that covered the aurat, diligent reading al qur'an, dhikr, alms, and noble character.

3. Implications Habituating Islamic behavior

Habituation of Islamic behavior can form the Muslim personality in the students in educational institutions. The Muslim person with the qur'ani character can be formed through the habituation of religious activities in the institution.

\section{REFERENCE}

Aan \& Cepi, Visionary Leadership Menuju Sekolah Efektif, Jakarta: Bumi Aksara, 2008. 
Abdul Ghofir, Zuhairini, Metodologi Pembelajaran Pendidikan Agama Islam, Malang: UIN Press dan UM Press, 2004.

A. Crow \& L Crow, Psikologi Pendidikan, Nur Cahaya, 1989.

Aly Munzier, Heri Nur, Watak Pendidikan Islam, Friska Agung Insani, Jakarta: 2008.

Arief, Armai, Pengantar ilmu dan Metodologi Pendidikan Islam, Jakarta: Ciputat Press, 2002.

Arikunto, Suharsimi, Prosedur Penelitian Suatu Pendekatan Praktis (Edisi Revisi VI), Jakarta: PT.Reineka Cipta, 2006.

Depdiknas, Kurikulum 2004 Standar Kompetensi pendidikan Agama Islam SMA dan MA, Jakarta: Pusat Kurikulum Balitbang Depdiknas, 2003.

Departemen Agama Republik Indonesia, Al-Qur'an dan Terjemahannya, Bandung: Gema Risalah Press, 2000.

Departemen Agama Republik Indonesia, Panduan Ekstra Kurikuler Pendidikan Agama Islam, Jakarta: Direktorat Jendral Kelembagaan Agama Islam, 2005.

Direktorat jendral pendidikan dasar, pendidikan karakter untuk membangun karakter bangsa, Jakarta: kemendiknas, 2011.

Djumhana, Hanna, Integrasi Psikologi Dengan Islam Menuju Psikologi Islami, Yogyakarta: Yayasan Insan Kamil Dan Pustaka Pelajar, 2001.

Fahmi, Abu Bakar, Religious Culture di Sekolah: Menggugah Hakekat Pendidikan Agama, dalam http://dunia.pelajarislam. or.id/dunia.pii/pendidikan/religiousculture-di-sekolahmenggugah-hakekat-pendidikan-agama.html

http:kamusbahasaindonesia.org/pembudayaan\#ixzz2t9wGXWLt, 15 Pebruari 2015.

http: Mudjiarahardjo.com, 5 Maret 2015.

Howa, Said, Perilaku Islam, Jakarta: Stuqdio Press, 1994.

Indra, Internalisasi Nilai-nilai Agama Islam Dalam Membentuk Siswa Berkarakter Mulia, Tesis, Tidak diterbitkan, Malang: 2012.

Johan, Mohamad, Implementasi Pendidikan Karakter di Pondok Pesantren, Tesis, Tidak diterbitkan, Malang: 2012.

Koentjoroningrat, Kebudayaan Mentalitet dan Pembangunan, Jakarta Gramedia, 1974.

Kusmana, Suherli, "Manajemen Strategik dalam Mengelola Satuan Pendidikan", Makalah, Cilacap: Seminar Nasional, 14 Juni 2009. 
Maunah, Binti, The Moslem Religion Student's Attitude on Learning of Arabic Literature in Al-Hikam Moslem Boarding School Malang, Baku, Azerbaijan to be published in May 30, 2015.

Maunah, Binti, Metodologi Pengajaran Agama Islam, Yogyakarta: Teras, 2009.

Marno, Islam by Management and Leadership, Jakarta: Lintas Pustaka, 2007.

Marukdin, Pendidikan Karakter Keislaman dan Kebangsaan di SMK, Tesis, Tidak diterbitkan, Malang: 2012.

Mashudi, Upaya Pembentukan Al Akhlak Karimah Santri Melalui Pembelajaran Al Akhlak, Tesis, Tidak diterbitkan, Surabaya: 2006.

Moleong, Lexy J, Metode Penelitian Kualitatif, Bandung: Remaja Rosdakarya, 2000.

Moleong, Metodologi Penelitian Kualitatif, Bandung: Remaja Rosdakarya, 2005.

Muhaimin, Nuansa baru pendidikan Agama Islam, Jakarta: Raja Grafindo persada, 2006.

Muhaimin, Paradigm Pendidikan Islam, Bandung: PT Remaja Rosada Karya, 2004.

Muhaimin, Pengembangan Kurikulum Pendidikan Islam Disekolah Madrasah Dan Perguruan Tinggi, Jakarta: PT Rajagrafindo Persada.

Muhaimin, Suti' ah dan Nur Ali, Penciptaan Suasana Religius Pada Sekolah di Kodya Malang, Malang: Hasil Penelitian tidak diterbitkan, 1998.

Muhajir, As' aril, Ilmu pendidikan perspektif kontekstual, Yogyakarta: Ar-Ruzz Media, 2011.

Mulyana, Rohmat, Mengartikulasikan Pendidikan Nilai, Bandung, Alfabeta: 2004.

Munzier S, Heri Nur, Watak Pendidikan Islam, Jakarta: Friska Agung Insani, 2008.

Nurfaiza, Integrasi pendidikan Karakter dalam Pembelajaran Pendidikan Kewarganegaraan dan Pembelajaran Pendidikan Agama Islam, Tesis, tidak diterbitkan, Yogyakarta: 2012.

Qomar, Mujamil, Meniti Jalan Pendidikan Islam, Yogyakarta: Pustaka Pelajar, 2003.

Rahman Shaleh, Abdul, Madrasah dan pendidikan Anak Bangsa, Jakarta: PT Raja Grafindo Persada, 2005.

Ramayulis, Metodologi Pengajaran, Batu Sangkar: Fakultas Tarbiyah IAIN Imam Bonjol, 1979.

Riyanto, Yatim, Metodologi Penelitian, Surabaya: SIC, 2004.

Sahlan, Asmaun, Mewujudkan Budaya Religius di Sekolah, Malang: UIN Maliki Press, 2010. 
Sagala, Syaiful, Manajemen Strategik Dalam Peningkatan Mutu Pendidikan; Pembuka Ruang Kreatifitas, Inovasi, Dan Pemberdayaan Potensi Sekolah Dalam Sistem Otonomi Sekolah, Bandung: Alfabeta, 2009.

Sagala, Syaiful, Manajemen Berbasis Sekolah dan Masyarakat Strategi Memenangkan Persaingan Mutu, Jakarta: Nimas Multima, 2006.

Shaleh, Abdul Rahman, Madrasah dan Pendidikan Anak Bangsa, Jakarta: PT Raja Grafindo Persada, 2005.

Sugiono, Memahami Penelitian Kualitatif, Bandung: Alfabeta, 2014.

Sugiyono, Metode Penelitian Pendidikan: Pendekatan Kuantitatif, Kualitatif, Dan R\&D, Bandung: Alfabeta, 2008.

Sueyabrata, Sumadi, Psikologi Pendidikan, Jakarta: CV Rajawali Press, 1984.

Syah, Muhibin, Psikologi Pendidikan Dengan Pendekatan Baru, Bandung: PT. Remaja Rosda Karya, 2003.

Tafsir, Ahmad, Metodologi Pengajaran Agama Islam, Bandung: PT. Remaja Rosdakarya, 2004.

Tanzeh, Ahmad, Pengantar Metode Penelitian, Yogyakarta: Teras, 2009.

Tim Redaksi Sinar Grafika, Undang-Undang sistem Pendidikan Nasional (Nomor 20 Tahun 2003), Jakarta: Sinar Grafika, 2007.

Undang-Undang Pemerintah Republik Indonesia No. 20 Tahun 2003 Tentang System Pendidikan Nasional, Bandung: Citra Umbara, 2003.

Usman, Basyirudin, Metodologi Pembelajaran Agama Islam, Jakarta: Ciputat Pers, 2002. W. Matja, Etnografi Desain Penelitian Kualitatif Dan Manajemen Pendidikan, Malang: Winaka Media, 2003.

Yasin, Fatah, Dimensi-Dimensi Pendidikan Agama Islam, Malang: UIN PRESS, 2008. 